\title{
USE OF INNOVATIVE TECHNOLOGIES BY INSURANCE MARKET ENTITIES. TELEMATICS IN CAR INSURANCE
}

\author{
Liliya Ignatovich ${ }^{1}$
}

\begin{abstract}
The purpose of the article is to substantiate the need for the use of innovative technologies by participants in the insurance market, namely, telematics in car insurance. The current state of the financial services market requires insurers to raise standards of work through the introduction of innovative products. It is determined that increasing the competitiveness of an insurance company should focus on providing the best personal services and meet the requirements of modernity and modern social trends, and therefore, make full use of the Internet: marketing and innovation. In view of this, the key task of the insurer's innovation activity is the maximum approximation of insurance services to the existing needs of the insured in insurance protection. It is possible to reach stable demand for this or that insurance service under the conditions of application of the world innovative insurance programs providing balance of qualitative and quantitative parameters of the insurance contract only. The relevance of the topic is that the Ukrainian insurance companies are forced to look for new opportunities to meet the needs of their customers in order to maintain competitive advantages and work effectively in the conditions of innovative development of insurance activity in the world. A promising area of further research is to assess the readiness of insurance market participants to use innovative insurance services. Methodology. The essence of telematics in car insurance is investigated. The state of the CASCO insurance market in Ukraine is analyzed. The main advantages of telematics use by the subjects of the insurance market of Ukraine are determined. Practical implications. It is proved that the introduction of innovative technologies opens new opportunities for the growth of additional premiums, improving the quality of service and minimizing insurance risks. Theoretical provisions on the need for ways to improve the innovative activities of the insurer have been further developed.
\end{abstract}

Key words: internet marketing, innovative technologies, innovation, insurance, IT technologies, CASCO, telematics, insurance telematics.

JEL Classification: M30, D40, L10

\section{Introduction}

Today in the insurance market of Ukraine, there are not only tendencies to use modern technologies in the field of business management, as well as new information technologies, but they are the driving force that allows insurance companies to interact with increasingly demanding and impatient customers successfully. Consumers, well versed in technological innovations and actively using them in everyday life, expect the appropriate technological level of service from insurers.

For the effective development of the insurance services market it is necessary to use the Internet marketing tools (Liliya Ignatovich, 2020). This expands the possibilities of communication between the subjects of the insurance market and increases the efficiency of business process management. The development of a digital strategy and its implementation is an inevitable step for the sustainable development of the insurance business in Ukraine. The rapid growth of the number of the Internet users, the expansion of the scope of digital technologies, the transition to electronic document flow and other innovative tools have led to changing the principles of the insurance market of Ukraine (Denisenko, 2015).

The number of communication channels is growing every year, which means that the opportunities for interaction with the audience are increasing. The introduction of innovations helps

\footnotetext{
Corresponding author:

${ }^{1}$ Zaporizhia National University, Ukraine.

E-mail: borisova.lilia@gmail.com

ORCID: https://orcid.org/0000-0002-4432-2226
} 
not only to sell insurance policies and quickly settle losses, but also to improve communication with the client, creating individual insurance products.

Unfortunately, most insurance companies in Ukraine do not use their marketing potential. This indicates that there are significant opportunities for further development of insurance companies, a prerequisite for this is the use of innovative technologies. The use of classical approaches to pricing is impossible and it is necessary to use only an individual approach. Standardized insurance products are being replaced by individual ones. Telematics is becoming one of the world's leading innovations in the insurance market.

The phrase "insurance telematics" is not clear to many people today. However, it is actively gaining momentum in the modern world, because it represents significant benefits for both insurance companies and car owners. Telematics in insurance is an opportunity to reduce the cost of the policy for a single driver. In other words, it is a special monitoring system, the main function of which is to track the driving characteristics of a particular person.

Insurance telematics allows you to collect data about each car owner, including driving style, travel frequency and mileage. In this case, the cost of the insurance policy is formed for each individual driver. In an effort to reduce insurance premiums, drivers become more attentive on the road, thereby reducing the risks for all road users. The Western world is already actively using telematics in insurance and Ukraine is still lagging behind.

\section{The main material}

The introduction and use of innovations for the insurance market of Ukraine is one of the most important conditions today. This is necessary for a prompt response to all the challenges of the modern world, the growth of consumer demand and for the opportunity to offer a current line of insurance services to specific customers.

One of the modern leading innovations in the insurance market is telematics, which has moved to insurance from the transport and logistics industry.
Telematics is literally a combination of the words telecommunications and computer science. This is a comprehensive use of telecommunications, information and communication technologies. This is a technology for obtaining information using telecommunications devices. Transport telematics allows you to control the location, movement and condition of an individual car or an entire fleet using a GPS receiver and electronic GPRS or 3G devices installed in each machine that interacts with the user and web-based software.

When insurance companies realized the benefits of telematics, they were able to study the "style" of driving their customers, and, taking this into account, to set the cost of a car insurance policy for each individual driver.

For example, the most popular type of insurance is CASCO, a voluntary type of vehicle insurance against damage, destruction, loss due to a road traffic accident, illegal seizure, fire, explosion, natural disaster, illegal actions of third parties, external influences of foreign objects (Law of Ukraine "On insurance", 1996).

\section{Analysis of the auto insurance market in Ukraine}

If we analyze the indicators of the financial market of Ukraine, the market of insurance services is the second in terms of capitalization among other non-banking financial markets. The total number of insurance companies as of March 31, 2020 was 225. Regarding car insurance, the indicators of collected premiums and insurance payments are presented below.

Despite the global crisis and quarantine measures, due to COVID-19, net car insurance premiums increased $(+7.4 \%)$. Thus, according to Table 1 , the amount of insurance premiums excluding the share of insurance premiums paid to resident reinsurers as of March 31, 2020 amounted to 3,317.4 million UAH. As of March 31, 2019, this indicator amounted to 3,087.8 million UAH.

Thus, according to Table 2, net insurance payments from car insurance in the first quarter of 2020 increased by 144.3 million UAH.

Table 1

Net insurance premiums for the first quarter of 2019-2020

\begin{tabular}{|c|c|c|c|}
\hline Type of insurance & 1st quarter 2019 & 1st quarter 2020 & Growth rates \\
\hline $\begin{array}{c}\text { Car insurance (CASCO, } \\
\text { SSLI, "Green Card") }\end{array}$ & 3087.8 million UAH & 3317.4 million UAH & $\begin{array}{c}229.6 \text { million UAH } \\
(7.4 \%)\end{array}$ \\
\hline
\end{tabular}

Source: compiled by the author independently, based on the Insurance TOP Journal, 2020 
Table 2

Net insurance payments for the first quarter of 2019-2020

\begin{tabular}{|c|c|c|c|}
\hline Type of insurance & 1 st quarter 2019 & 1 st quarter 2020 & Growth rates \\
\hline $\begin{array}{c}\text { Car insurance (CASCO, } \\
\text { SSLI, "Green Card") }\end{array}$ & 1580.3 million UAH & 1724.6 million UAH & $\begin{array}{c}6144 \text { million UAH } \\
(9.1 \%)\end{array}$ \\
\hline
\end{tabular}

Source: compiled by the author independently, based on the Insurance TOP Journal, 2020

Analyzing the data of Figure 1, the volume of gross insurance premiums with CASCO for the first quarter of 2020 amounted to 1830.9 million UAH. The growth rate of insurance premiums on CASCO was $5.7 \%$. The volume of gross insurance payments for land transport insurance (CASCO) for the first quarter of 2020 amounted to 934.7 million UAH, which is $2.0 \%$ more than for the same period in 2019.

The assessment of the state of the car insurance market revealed that the demand for motor insurance services and direct CASCO insurance from potential policyholders is growing every year, despite the general state of the market and has a positive effect on the introduction of innovations.

Regarding the tariffpolicy of insurance companies, each insurance company has its own insurance programs CASCO, with its own conditions and basic coefficients. Analyzing information about insurance cases, companies seek to optimize the ratio of insurance premiums to insurance payments. Based on the obtained data, insurance coefficients are set, according to which the cost of a CASCO policy for a specific car owner is calculated.

The most advantageous offers for CASCO insurance are provided to adult and experienced drivers who have the lowest risk of getting into an accident. It should be noted that the cost of
CASCO for a particular car is influenced by the following factors: theft statistics for this model in the area and the availability of special anti-theft devices, the cost of spare parts, the size of the deductible, the presence of insurance cases for previous periods, additional options. departure of the emergency commissioner, evacuation, collection of documents, etc.).

The cost of CASCO is influenced by the city of registration of the car: for example, CASCO in Kyiv is more expensive than in the regions, as according to statistics, the probability of an insured event in Kyiv is higher than in other cities.

Telematics allows you to track driving technique, and then develop a system of discounts or bonuses for customers for safe driving. This technology is also useful because it will later help to reduce the number of accidents and make traffic safer for all its participants.

\section{Telematics as an innovative tool for the development of the insurance market}

The most common type of telematics device is a small device that is inserted into the diagnostic port of the car under the wheel. When the car is moving, it collects data that determines the driving characteristics of the client. Communication is

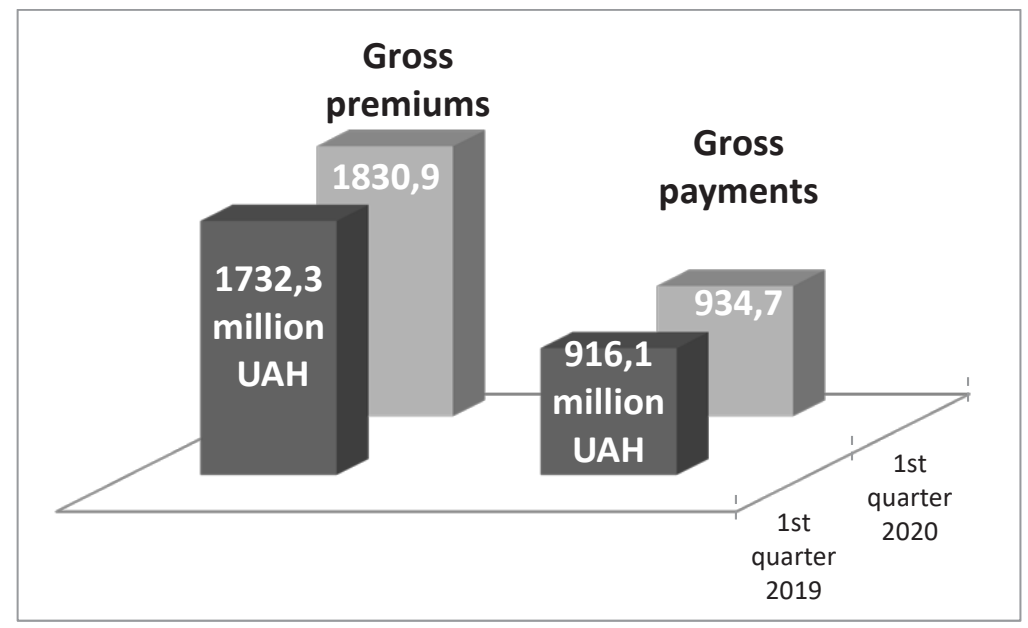

Figure 1. Dynamics of the main indicators of CASCO 
provided by a SIM-card of one of the mobile operators, which is used to transmit telematic information to the provider's server. This data is available both to the insurance company on a special web portal and to the client, who can monitor their performance through the mobile application and additionally receive recommendations on the technique and style of driving. The mobile application is installed on the client's smartphone with Android or iOS for visualization and data transfer for processing. The insurance company has the opportunity to view the analytics on the web portal (The official website of the Benish GPS company, 2020).

Driving style is evaluated on a scale of points, on the basis of which the insurer determines the individual discount. Also in the mobile application, the insured driver can read tips on how to increase driving safety. Following the recommendations of the system, you can reduce the probability of an accident by $30 \%$.

Under the terms of the insurance program, the telematics device and the CASCO SMART application are provided free of charge. The application is available for download in the Apple Store or Google Play.

Insurers in the United States began to use telematics in insurance for the first time. Since 1998, the United States has introduced products that allow you to pay for hull insurance based on the number of miles traveled by the car. From the fall of 2014 in America, it is recommended to install telematics devices in all new cars.

In Europe, the law of Mario Monti (Italy) came into force in June 2012: telematics devices are installed in all new cars. Their data are taken into account by the courts in Great Britain and Italy.

In Ukraine, the use of insurance telematics technologies is at an early stage, because it has no technical base and specialized software. We only begin to use such devices in Ukraine.

The first and only insurance company to launch an insurance product with telematics is AXA Insurance. CASCO Smart was launched in 2016.

In 2018, Allied Market Research published a report entitled "Global Commercial Telematics Market by Solution Type (OEM and Aftermarket), Application (Solutions and Services), and End User (Transportation and Logistics, Insurance, Healthcare, Media \& Entertainment, Vehicle Manufacturers/Dealers, and Government Agencies): Global Opportunity Analysis and
Industry Forecast, 2018-2030". According to the report, the global market for commercial telematics was 27.07 billion USD in 2017. It is expected that by 2030 it will amount to 144.44 billion USD. The average annual growth rate with a forecast until 2022 is 14\% (Annual review and summary financial statements, Allied Market Research, 2020).

In insurance telematics, two main approaches are used:

1. "Pay as you drive". Mileage monitoring, socalled low mileage.

2. "Pay how you drive". More parameters are taken into account: driving time, speed mode, mileage. The total number of indicators in this case can reach two or three dozen.

The data obtained are processed and make it possible to assess the level of risk of each individual driver directly. Telematics also allows vehicle owners to control each car. Such monitoring nullifies all fraudulent practices of the park staff.

It is important to note that the telematics device does not collect personal data: no information about the location of the car, no GPS coordinates, no visited places, no tracks.

The main advantages of using telematics for insurance market participants are:

1. Individual risk accounting.

2. Creation of new products and introduction of additional services

3. Development of loyalty programs for each client.

4. Transparency of pricing.

5. Reducing the number of insurance fraud cases.

6 . Reducing the costs of insurance companies.

7. Additional channel of communication with the client via mobile application.

8. Improving driving culture and reducing the number of accidents.

9. Ability to transmit information about the accident instantly.

\section{Conclusions}

Globalization requires insurers to use innovative tools. The evolution of wireless connection, Big Data and the Internet is transforming even such conservative areas as insurance.

According to foreign experience, the level of innovation of the insurer is one of the determining factors in increasing its competitiveness. Focusing on consumer needs requires insurers to raise standards of performance through the introduction of innovative products. 
Despite the annual decrease in the number of insurance companies in Ukraine, the level of motor insurance is growing every year. CASCO is one of the most common types of voluntary insurance for owners of land vehicles. The use of digital technologies gives insurers new opportunities to improve the quality of customer service, better selection of insurance risks, prevention of losses.

The basis of insurance telematics is the registration of driving style, which allows insurance companies to create new offers for customers. But telematics in car insurance is not only a means of managing the insurer's risks to reduce the cost of the policy, but also a tool for interacting with the client through a mobile application.

In Ukraine, the use of insurance telematics technologies is at the early stage. Insurers need to be prepared to work with huge amounts of information, have specialized software and have a powerful back office. All this requires significant investment in development and operation.

The state of the car insurance market and the experience of foreign countries are analyzed. The necessity of using insurance telematics as a new level of cooperation with clients is proved.

It has been found that telematics devices allow you to determine the cost of the insurance policy more accurately, reduce the loss of the insurance company by creating personal insurance products, increase the level of service and generally reduce the incidence of insurance fraud. The current state of the insurance market requires insurers to raise standards of work immediately through the use of insurance telematics, which is an important area in the development of the insurance market.

\section{References:}

Annual review and summary financial statements Allied Market Research (2018). Retrieved June 28, 2020, from: https://www.prnewswire.com/news-releases/commercial-telematics-market-144-44billion-by-2030-at-13-8-cagr-says-amr-838252834/2020-1-3.html

Denisenko, M. P. (2015). Innovations on the insurance market of Ukraine. Investments: practice and experience, no. 21 , pp. $79-82$.

Statistics of Insurance TOP in Ukraine (2020). Forinsurer. Insurance TOP. Retrieved September 10, 2020, from: https://forinsurer.com/stat

Law of Ukraine "On Insurance" (1996). VVR Ukraine, (18):78. Retrieved September 10, 2020, from: http://search.ligazakon.ua/1_doc2.nsf/link1/Z960085.html

Liliya Ignatovich (2020). Internet marketing as an instrument for developing insurance services. Bulletin of Zaporizhzhia National University. Economic Sciences, no. 2(46), p. 123.

The official website of the Benish GPS company. Retrieved September 05, 2020, from: http://www.benishgps.com 